T

\section{THE TAN KAH KEE FOUNDATION}

Level 1, 43 Bukit Pasoh Road, 089856, Singapore Tel: (65) 62226620

Fax: (65) 64621192

Email: tkkf@tkkfoundation.org.sg

Website: www.tkk.wspc.com.sg

The mission of The Tan Kah Kee Foundation is to carry on the charity works and to foster the Tan Kah Kee spirit in entrepreneurship and dedication to education. Over the years, the Foundation has been actively engaged in the promotion of education and culture. Today, its influence has been extended beyond the Chinese Community in Singapore and has begun to reach out to the region.

\section{Tan Kah Kee Postgraduate Scholarship}

Subjects: All subjects.

Purpose: To provide financial assistance to students pursuing their postgraduate studies.

Eligibility: Open to citizens and permanent residents of Singapore who are pursuing full-time Master's degree or PhD in any discipline, regardless of race or religion. Candidates are appraised on their academic achievements, outstanding personal character and bilingual capabilities. Level of Study: Doctorate, Postgraduate

Type: Scholarship

Value: Singaporean $\$ 10,000$ for overseas students, Singaporean $\$ 7,000$ for local universities

Frequency: Annual

Application Procedure: Applicants can download the application form from the website www.tkkfoundation.org.sg/foundation/post eng.shtml.

Closing Date: May 30th

Funding: Foundation

Contributor: Tan Kah Kee Foundation

Additional Information: Application is open in May every year. Shortlisted applicants will be informed to attend an interview in the month of June or July.

\section{TANTE MARIE'S COOKING SCHOOL}

271 Francisco Street, San Francisco, CA, 94133 ,

United States of America

Tel: (1) 4157886699

Fax: (1) 4157888924

Email: peggy@tantemarie.com

Website: www.tantemarie.com

Tante Marie's Cooking School, located in San Francisco was founded as a full-time school in 1979. It is one of the first schools of fine cooking offering all-day, year-round classes for people who are serious about cooking well. Graduates from Tante Marie's have interesting and varied careers. In addition to offering professional courses for people wanting to begin a career in culinary or pastry, Tante Marie's welcomes interested avocational students in the Evening Series, Weekend Workshops, One-Day Workshops and Cooking Vacations. There are also cooking parties on weekend evenings where groups of up to 30 people cook together. The emphasis at Tante Marie's is in building confidence in the kitchen.

\section{The Absolute Taste Scholarship}

Subjects: Cooking.

Purpose: To make the candidates learn cooking professionally. Eligibility: All prospective students ordinarily resident in the British Isles who will have attained at least 16 years of age and be under 25 years of age on commencement of the course.

Level of Study: Unrestricted

Type: Scholarship

Value: Up to 100 per cent of the course fee

Frequency: Annual

Country of Study: United States of America

Application Procedure: Check website for further details.

Closing Date: June 7th

Funding: Private

Additional Information: Please refer to the website for details.
For further information contact:

Email: info@tantemarie.co.uk

Website: http://www.tantemarie.co.uk/news/scholarships_full.php? $\mathrm{ID}=5$

\section{TANZANIA COMMUNICATIONS REGULATORY AUTHORITY (TCRA)}

Tanzania Communications Regulatory Authority (TCRA),

Mawasiliano Towers, 20 Sam Nujoma Road, Dar Es Salaam, Tanzania

Tel: $(255)+2221997608 / 2224120112$

Fax: (255) + $222412009 / 222412010$

Email: dg@tcra.go.tz

Website: http://www.tcra.go.tz/

The Tanzania Communications Regulatory Authority (TCRA) is a quasi independent Government body responsible for regulating the communications and broadcasting sectors in Tanzania. It was established under the TCRA Act no. 12 of 2003 to regulate the electronic communications, and postal services, and management of the national frequency spectrum in the United Republic of Tanzania.

\section{TCRA ICT Scholarship}

Purpose: The scholarship offers Tanzania students the opportunity to obtain degrees in the Information and Communication Technologies (ICT) and related areas.

Eligibility: The scholarship will be awarded on the basis of academic merit and an interview to be conducted by the Scholarship Panel.

Level of Study: Postgraduate

Type: Scholarship

Length of Study: All scholarships are provided for the specified duration of a particular degree course

Country of Study: Tanzania

No. of awards offered: Two master's scholarships and one PhD scholarship available

Closing Date: July 20th

Funding: International Office

Additional Information: Tanzanian students can apply for these ICT scholarships.

\section{THE TE PÔKAI TARA UNIVERSITIES NEW ZEALAND}

PO Box 11915, Manners Street, Wellington, 6142, New Zealand Tel: (64) 4043818500

Fax: (64) 4043818501

Email: kiri@nzvcc.ac.nz

Website: www.nzvcc.ac.nz

Contact: Kiri Manuera, Scholarships Manager

The New Zealand Vice Chancellors Committee (NZVCC) was established by the Universities Act 1961, which replaced the federal University of New Zealand with separate institutions. Today the Committee represents the interests of New Zealand's 8 universities. The NZVCC represents the interests of the New Zealand university system to government, its agencies and the public through a range of forums and communications from joint consultative groups to electronic and print publications.

The Association of University Staff Crozier Scholarship Subjects: History, management, organization, economics, economic and social impact, sociology and pedagogy.

Purpose: To provide funds for individuals to undertake research towards an Honours, Master's or Doctoral degree and who are undertaking research or scholarly enquiry for a research project, theses or dissertation at a New Zealand or overseas university or research institution in the related fields.

Eligibility: Open to applicants who are citizens or permanent residents of New Zealand who have resided in New Zealand for at least 3 years. Applicants should also have completed the requirements for a Bachelors degree or equivalent in a field appropriate to their intended study at a New Zealand university.

Level of Study: Postgraduate 
Type: Scholarship

Value: New Zealand $\$ 5,000$

Length of Study: 3 Years

Frequency: Annual

Country of Study: New Zealand

No. of awards offered: 1

Application Procedure: Check the website.

Closing Date: October 1st

Contributor: New Zealand Vice Chancellors Committee Wellington

\section{Cambridge Commonwealth Trust Prince of Wales \\ Scholarship}

Subjects: All subjects

Purpose: To enable bright, young students of high academic ability to study at Cambridge University in Britain.

Eligibility: Open to citizens of New Zealand who wish to pursue a course of research leading to a PhD degree at Cambridge University. The candidate should have also applied for admission to Cambridge. Level of Study: Doctorate, Research

Type: Scholarship

Value: The scholarship covers the University Composition Fee at the home rate along with a maintenance allowance

Length of Study: 3 years

Frequency: Annual

Study Establishment: Cambridge University

Country of Study: United Kingdom

Application Procedure: Check the website

Closing Date: October 1st

\section{Claude McCarthy Fellowships}

Subjects: All subjects.

Purpose: To enable graduates of a New Zealand university to undertake original work or research.

Eligibility: Open to any graduate of a New Zealand university.

Level of Study: Postgraduate, Doctorate

Type: Fellowship

Value: Varies. Funding is available for the year following application.

Length of Study: Usually no more than 1 year

Frequency: Annual

Country of Study: Any country

No. of awards offered: Varies, depending upon funds available, but usually $12-15$

Application Procedure: Applicants must write for details

Closing Date: August 1st

Funding: Private

Contributor: The Claude McCarthy Trust

Additional Information: Further information is available on request.

\section{Dick and Mary Earle Scholarship in Technology}

Subjects: Innovation and product development and bioprocess technology.

Purpose: To provide funds for individuals to undertake research towards a Masterate or Doctorate degree at a New Zealand university or research institution in related fields.

Eligibility: Open to candidates who are citizens or permanent residents of New Zealand, who have resided in New Zealand for at least 3 years and have completed the requirements for a BTech, BEng, BE degree or equivalent, with Honours at a New Zealand university. Level of Study: Postgraduate

Type: Scholarships

Value: New Zealand $\$ 17,000$ per year at Master's level and New

Zealand $\$ 20,000$ per year at PhD level

Frequency: Annual

Country of Study: New Zealand

No. of awards offered: 2

Closing Date: October 1st

\section{Gordon Watson Scholarship}

Subjects: International relationships and social and economic conditions.

Purpose: To enable the holder to study abroad questions of international relationships or social and economic conditions, at Masters or PhD level.

Eligibility: Candidates must be New Zealand citizens or permanent residents. Open to holders of an Honours degree, or a degree in theology from a university in New Zealand. Candidates must undertake to return to New Zealand after the scholarship period for not less than 2 years.

Level of Study: Postgraduate

Type: Scholarship

Value: New Zealand $\$ 12,000$ per year

Length of Study: Up to 3 years

Frequency: Annual

Study Establishment: Any approved university

No. of awards offered: 1

Application Procedure: Candidates must write for details.

Closing Date: March 1st

Funding: Private

Contributor: The Gordon Watson Trust

Additional Information: Further information is available on request

\section{B. Wood Travelling Scholarship}

Subjects: All subjects.

Purpose: To allow graduates to undertake doctoral studies in the United Kingdom.

Eligibility: Open to all holders of postgraduate scholarships from any faculty of any university in New Zealand, provided that application is made within 3 years of the date of graduation.

Level of Study: Doctorate

Type: Scholarship

Value: New Zealand $\$ 3,000$ per year, as a supplement to another postgraduate scholarship

Length of Study: Up to 3 years

Frequency: Annual

Study Establishment: A university or institution of university rank

Country of Study: United Kingdom

No. of awards offered: 1

Application Procedure: Applicants must write for details.

Closing Date: March 1st

Funding: Private

Contributor: The L B Wood Trust

Additional Information: Further information is available on request.

\section{Shirtcliffe Fellowship}

Subjects: Arts, science, law, commerce and agriculture.

Purpose: To assist students of outstanding ability and character who are graduates of a university in New Zealand, in the continuation of their doctoral studies in New Zealand or the Commonwealth.

Eligibility: A citizen of New Zealand. A graduate of a New Zealand university. Planning to register or be currently registered as a doctoral candidate at a university in New Zealand or another Commonwealth country.

Level of Study: Doctorate

Type: Fellowship

Value: New Zealand $\$ 5,000$ as a supplement to the postgraduate scholarship emolument

Length of Study: Up to 3 years

Frequency: Annual

Study Establishment: A suitable Institute of Higher Education

No. of awards offered: 1

Application Procedure: Candidates must write for details.

Closing Date: March 1st

Funding: Private

Additional Information: Further information is available on request.

\section{William Georgetti Scholarships}

Subjects: All subjects.

Purpose: To encourage postgraduate study and research in a field that is important to the social, cultural or economic development of New Zealand.

Eligibility: Candidates must be New Zealand citizens or permanent residents. Open to graduates who have been resident in New Zealand for 5 years immediately before application and who are preferably aged between 21 and 28 years.

Level of Study: Postgraduate

Type: Scholarship

Value: Up to $\$ 20,000$ per year for Masters study. For those students studying overseas the emolument shall be at a rate of up to $\mathrm{NZ} \$ 45,000$ per year.

Length of Study: 3 year 
Frequency: Annual

Study Establishment: Suitable universities

Country of Study: Any country

No. of awards offered: Varies

Application Procedure: Applicants must write for details.

Closing Date: October 1st

Funding: Private

Contributor: The Georgetti Trust

Additional Information: Further information is available on request.

\section{TEAGASC (IRISH AGRICULTURE AND FOOD DEVELOPMENT AUTHORITY)}

\author{
Oak Park, Carlow, Ireland \\ Tel: (353) 599170200 \\ Fax: (353) 599182097 \\ Email: info@teagasc.ie \\ Website: www.teagasc.ie \\ Contact: Debbie Murphy
}

Teagasc (Irish Agriculture and Food Development Authority) is the parastatal body responsible for agricultural and food research, farm advisory services and farmer education in the Republic of Ireland. Its research programme includes foods, dairy cows, beef cattle, pigs, sheep, crops, horticulture, environment, rural economics and sociology at eight research centres.

\section{Teagasc Walsh Fellowships}

Subjects: Any subject relevant to food and agriculture in Ireland, e.g. animal sciences, plant sciences, physical or earth sciences, environment, economics and rural development.

Purpose: To support MSc and PhD projects on topics relevant to the overall Teagasc research programme on agriculture and food.

Eligibility: Applicants must be college faculty members who, in cooperation with Teagasc researchers, submit proposals relevant to the Teagasc programme on agriculture and food in Ireland. If successful, they then select postgraduate students for MSc or PhD programmes as Walsh Fellows. Applications are not accepted from individual students or for taught non-research postgraduate courses.

Level of Study: Doctorate, Postgraduate, Research

Type: Fellowship

Value: The value of the scholarship is $€ 22,000$ per year. The successful applicant will be required to pay a postgraduate registration fee of approx. $€ 6,000$ per year (EU students) or approx. $€ 12,000$ per year (non-EU students)

Length of Study: Up to 2 years for an MSc, maximum of 4 years for a $\mathrm{PhD}$

Frequency: Annual

Study Establishment: Any third-level college, in association with a Teagasc Research Centre

Country of Study: Ireland

No. of awards offered: Approx. 40

Application Procedure: Applicants must apply for an information brochure, which includes an application form, available on request. Students who wish to apply for a pre-awarded fellowship should check the Teagasc website (www.teagasc.ie) that contains a complete list of fellowships awarded with supervisor contact details.

Closing Date: Please refer website

Funding: Government

Contributor: Teagasc's own resources, via the Irish Government and the European Union agri-food industry

No. of awards given last year: 40

No. of applicants last year: 120

Additional Information: The full list of awarded fellowships are posted on the Teagasc website (www.teagasc.ie) mid-April annually.

\section{TECHNICAL UNIVERSITY OF DENMARK (DTU)}

Anker Engelunds Vej 1 Bygning 101A, 2800 Kgs. Lyngby, Denmark Tel: $(45)+(0) 45251156$

Email: oerstedpostdoc@adm.dtu.dk

Contact: COFUND secretariat
Technical University of Denmark (DTU) is recognized internationally as a leading university in the areas of the technical and the natural sciences, renowned for business-oriented approach, focus on sustainability, and amazing study environment.

H.C. Ørsted Fellowships for International Researchers

Subjects: Mathematics, physics, space research and informatics; chemistry, biotechnology and chemical engineering; electronics and communication; construction, production, buildings and transportation; life science.

Purpose: The programme is named after Hans Christian Ørsted, discoverer of electro-magnetism and founder of the University and achieves the goals of Marie Skłodowska-Curie COFUND by increasing the European-wide mobility possibilities for training and career development of experienced researchers. The Programme will contribute to the researcher's career development, broadening and deepening individual competencies through exposure to an international and multidisciplinary environment.

Eligibility: The Candidate will will normally be required to defend the $\mathrm{PhD}$ thesis in June but please check the website for the year in which you are applying for the confirmed date.

Level of Study: Postdoc, Research

Type: Fellowship

Value: The grant will cover the salary for the postdoc fellow for up to 2 years, but not research costs. Research costs must be provided by the hosting research department. It is therefore recommended that the research plan is developed in cooperation with the relevant research department and potential supervisor at DTU.

Length of Study: 2 years

Country of Study: Denmark

No. of awards offered: 16

Application Procedure: Applications must be submitted as one compiled PDF file containing all material via DTU's online submission form at www.dtu.dk/english/career.

Closing Date: February 23rd

Contributor: Marie Sklodowska-Curie Actions

Additional Information: For any queries please contact oerstedpostdoc@adm.dtu.dk.

\section{THE TECHNISCHE UNIVERSITEIT DELFT (TUD)}

Post bus 5, 2600 AA Delft, Netherlands Tel: (31) 152789111

Fax: (31) 152781855

Email: info@tudelft.nl

Website: www.tudelft.nl/msc

Founded in 1842, the Delft University of Technology is the oldest, largest, and most comprehensive technical university in the Netherlands. It is an establishment of both national importance and significant international standing. Renowned for its high standard of education and research, TU Delft collaborates with other educational establishments and research institutes, both within and outside of the Netherlands. TU Delft aims at being an 'interactive partner' to social issues, committed to answering its multifaceted demands and initiating changes to benefit people in the future.

The Shell Centenary Scholarship Fund, Netherlands Subjects: All master programmes under the TSCSF scholarship scheme.

Purpose: To give students the opportunity to study at the TUD and gain skills that will make a long-term contribution to the further development of their countries.

Eligibility: Open to candidates who are nationals of and resident in any country other than the ones listed in 'Additional Information' and aged 35 or under, intending to study a subject that will be of significant value in aiding the sustainable development of their home country, fluent in spoken and written English, and neither a current nor former employee of the Royal Dutch/Shell Group of companies.

Level of Study: Postgraduate

Type: Scholarship

Value: Full-cost scholarship including tuition fees, international travel, living allowances and health insurance

Length of Study: 2 years 


\section{Frequency: Annual}

Country of Study: Netherlands

No. of awards offered: 90

Application Procedure: Applicants must have been admitted to a

MSc programme of TU Delft, the International Office will subsequently send you the application form by email, the International Office will check your application on the basis of the Royal Dutch/Shell criteria. Closing Date: December 15th (check with website)

Contributor: TUD with support from The Shell Centenary Scholarship Fund (TSCSF)

Additional Information: Countries not eligible: Australia, Austria,

Belgium, Canada, Cyprus, Czech Republic, Denmark, Estonia,

Finland, France, Germany, Greece, Hungary, Iceland, Ireland, Italy, Japan, Latvia, Lithuania, Luxembourg, Malta, The Netherlands, New Zealand, Norway, Poland, Portugal, Slovenia, Slovakia, Spain,

Sweden, Switzerland, UK, and US.

\section{For further information contact:}

International Office, Julianalaan 134, 2628 BL Delft, Netherlands Tel: (31) 152785690

Email: msc2@tudelft.nl

\section{TEL AVIV UNIVERSITY (TAU)}

PO Box 39040, Tel Aviv, 6997801, Israel Tel: (972) 36408111

Email: tauinfo@post.tau.ac.il

Website: www.tau.ac.il

Tel Aviv University (TAU) was founded in 1956 and is located in Israel's cultural, financial and industrial heartland, TAU is the largest university in Israel and the biggest Jewish university in the world. TAU offers an extensive range of programmes in the arts and sciences.

\section{TAU Scholarships}

Subjects: History and contemporary music.

Purpose: To encourage innovative and interdisciplinary research that cuts across traditional boundaries and paradigms.

Eligibility: Open to candidates who have registered for their Doctoral or Postdoctoral degree.

Level of Study: Doctorate, Postdoctorate

Type: Scholarships

Value: Varies

Frequency: Annual

No. of awards offered: Varies

Application Procedure: Applicants can download the application form from the website. The completed application form along with a curriculum vitae and a description of research project with a list of publications is to be sent.

Closing Date: Varies

Additional Information: Applications if sent by email, must be directed to ddprize@post.tau.ac.il.

\section{For further information contact:}

The Lowy School for Overseas Students, Center Building, Tel-Aviv University, Ramat Aviv, Tel Aviv, 69978, Israel

Email: jkc@jackkentcookefoundation.org

Website: http://international.tau.ac.il/prospective-students/financialterms/scholarships.html

Contact: Ms Smadar Fisher, Director, Dan David Prize

\section{TENOVUS SCOTLAND}

Small Research Grants, 232-242 St. Vincent Street,

Glasgow, G2 5RJ, Scotland

Tel: (44) 1412216268

Fax: (44) 1292311433

Email: gen.sec@talk21.com

Website: www.tenovus-scotland.org.uk

Contact: I M'Fadzean, General Secretary

Tenovus Scotland supports innovative and pilot medical research projects carried out by young researchers who may not have a track record, across the full spectrum of Medicine and Dentistry.
Tenovus Scotland Small Research Grants

Subjects: Medicine, dentistry, medical sciences and allied areas. Purpose: To foster high-quality research within the healthcare professions in Scotland.

Eligibility: Medical professionals of Scotland. (1) No restrictions on age although preference is for young researchers seeking to establish a track record. (2) Grants conditional on the work being carried out in a Scottish University/Teaching at an NHS Trust Hospital. (3) No restriction on nationality provided they meet the above criteria. Level of Study: Research

Type: Grant

Value: Up to $£ 10,000$

Frequency: Annual

Country of Study: Scotland

Application Procedure: Application forms must be filled, applications from investigators lacking support in the early stages of a new project are encouraged. Applications may be invited for salary support or for research studentships.

Closing Date: September 15th (Edinburgh), February 15th and September 15th (Grampian and Strathclyde), May 1st and December 1st (Tayside)

Funding: Individuals, trusts

No. of awards given last year: 42

No. of applicants last year: 89

Additional Information: Please see the website for further details www.tenovus-scotland.org.uk/ForResearchers.html.

\section{TERRA FOUNDATION FOR AMERICAN ART}

120 East Erie Street, Chicago, IL, 60611, United States of America Tel: (1) 3126643939

Website: www.terraamericanart.org

An organization focused on historical art of the US through grants, initiatives, partnerships, art collection, and other resources. Chicago.

\section{Research Travel Grants to the United States}

Purpose: To enable scholars outside the US to consult resources that are only available within the US. These grants provide support for research on topics concerning American art and visual culture prior to 1980. Eligibility: The foundation only accepts proposals from doctoral students and postdoctoral and senior scholars outside the US. Type: Travel grant

Value: Three grants of US $\$ 6,000$ each will be offered to researchers at doctoral level. Three grants of US $\$ 9,000$ each will be offered to postdoctoral researchers who have been awarded their doctorate within the past ten years

Length of Study: Short-term travel (3 months maximum)

Frequency: Annual

No. of awards offered: $9-13$

Closing Date: January 15th

Additional Information: For further information, please check www. terraamericanart.org/scholarship/grants-and-fellowships/doctoralpostdoctoral-research-travel-grants-to-the-united-states/.

\section{THAILAND NATIONAL COMMISSION FOR UNESCO}

Asia-Pacific Regional Bureau for Education, Mom Luang Pin Malaku Centenary Building, 920 Sukhumvit Road, Prakanong, Klongtoey, Bangkok, 10110, Thailand

Tel: (66) 23910577

Fax: (66) 23910866

Email: bangkok@unesco.org

Website: http://www.unescobkk.org/

Contact: Ms Chatuporn, Secretary General

\section{Fulbright - Cambridge Scholarship}

Subjects: All subjects.

Purpose: To pursue PhD study at the University of Cambridge.

Eligibility: US citizens are eligible to apply.

Level of Study: Doctorate

Type: Award 
Value: Full fees and living stipend for duration of $\mathrm{PhD}$ programme Frequency: Annual

Study Establishment: Cambridge

Country of Study: United Kingdom

No. of awards offered: 1

Application Procedure: Please check at http://us.fulbrightonline.org/ applynow.html.

Closing Date: Deecember 4th

Funding: Government

Additional Information: Please check for more information at www. fulbright.co.uk.

\section{THIRD WORLD ACADEMY OF SCIENCES (TWAS)}

\author{
TWAS Executive Director, ICTP Enrico Fermi Building, \\ Room 108, Italy \\ Tel: (39) 0402240327 \\ Fax: (39) 040224559 \\ Email: edoffice@twas.org \\ Website: www.twas.org \\ Contact: Professor Romain Murenzi, Executive Director
}

The Third Word Academy of Sciences (TWAS) is an autonomous international organization that promotes and supports excellence in scientific research and helps build research capacity in the South.

\section{CAS-TWAS Fellowship for Postdoctoral Research in \\ China}

Subjects: All areas of the natural sciences.

Purpose: To enable scholars who wish to pursue postdoctoral research to undertake research in laboratories or institutes of the Chinese Academy of Sciences.

Eligibility: Candidates must have a $\mathrm{PhD}$ and be nationals of a developing country other than China. They must also be regularly employed at a research or teaching institution in their home country. The maximum age limit is 40 years.

Level of Study: Postdoctorate

Type: Fellowship

Value: CAS will cover food, accommodation, emergency medical aid, in addition the international travel (return economy class fare by shortest route) will be covered by TWAS

Length of Study: Up to 1 year

Frequency: Annual

Study Establishment: CAS

Country of Study: China

No. of awards offered: Up to 15

Application Procedure: Applicants must send one copy of the application form to TWAS and three copies to CAS. Application forms can be obtained from the TWAS website.

Closing Date: March 31st and August 31st (check with website) Funding: Government

Contributor: Chinese Academy of Sciences (CAS) and TWAS Additional Information: CAS has 5 academic divisions, 11 local branches, 84 research institutes and 3 universities or colleges, distributed throughout the country.

For further information contact:

Division of International Organization Programmes, Chinese Academy of Sciences, 52 Sanlihe Road, Beijing, 100864, China

Website: http://twas.ictp.it/prog/exchange/fells/fells-pdoc/cas-pdoc Contact: Mr Wang Zhenyu, Deputy Director

\section{CAS-TWAS Fellowship for Postgraduate Research in \\ China \\ Subjects: All areas of the natural sciences.}

Purpose: To carry out research towards the final year of a PhD programme in China.

Eligibility: Candidates must have a Master's degree in natural sciences, be nationals of a developing country other than China and be registered for a PhD in their home country. The maximum age limit is 35 years.

Level of Study: Postgraduate

Type: Fellowship
Value: Covers food, accommodation and international travel. There is no provision for family members

Length of Study: 1 year

Frequency: Annual

Study Establishment: CAS

Country of Study: China

No. of awards offered: Up to 20

Application Procedure: Applicants must send one copy of the application form to TWAS and three copies to CAS. Application forms can be obtained from the TWAS website.

Closing Date: August 31st

Funding: Government

Contributor: Chinese Academy of Sciences (CAS) and TWAS

No. of awards given last year: New

Additional Information: CAS has 5 academic divisions, 11 local branches, 84 research institutes and 3 universities or colleges distributed throughout the country.

For further information contact:

Division of International Organization Programmes, Chinese Academy of Sciences, 52 Sanlihe Road, Beijing, 100864, China

Website: http://twas.ictp.it/prog/exchange/fells/fells-pg/cas-pg

Contact: Mr Wang Zhengu, Deputy Director

\section{CAS-TWAS Fellowship for Visiting Scholars in China}

Subjects: All areas of the natural sciences.

Purpose: To pursue advanced research in the natural sciences.

Eligibility: Applicants must have a $\mathrm{PhD}$, a regular research assignment and at least 5 years postdoctoral research experience. Chinese nationals are not eligible. The maximum age limit is 55 years.

Level of Study: Research

Type: Fellowship

Value: International travel (return economy class by the shortest route) and visa expenses will becovered by TWAS. CAS will provide a standard monthly allowance which should be used to cover living costs, such as accommodation, food and health insurance

Length of Study: 1-3 months

Frequency: Annual

Study Establishment: CAS

Country of Study: China

No. of awards offered: Up to 15

Application Procedure: Applicants must send one copy of the application to TWAS and 3 copies to CAS. Application forms can be obtained from the TWAS website.

Closing Date: August 31st

Funding: Government

Contributor: Chinese Academy of Sciences (CAS) and TWAS Additional Information: CAS has 5 academic divisions, 11 local branches, 84 research institutes and 3 universities or colleges distributed throughout the country.

For further information contact:

Division of International Organization Programmes, Chinese Academy of Sciences, 52 Sanlihe Road, Beijing, 100864, China

Website: http://twas.ictp.it/prog/exchange/fells/fellows-adv/cas-vis Contact: Mr Wang Zhenyu, Deputy Director

\section{CNPq-TWAS Doctoral Fellowships in Brazil}

Subjects: All areas of the natural sciences.

Purpose: To enable scholars from developing countries (other than Brazil) to undertake research in Brazil.

Eligibility: Applicants must hold a Master's degree or equivalent, and be proficient in either English, French, Portuguese or Spanish. Open to nationals of a developing country other than Brazil. The maximum age limit is 30 years.

Level of Study: Postgraduate

Type: Fellowship

Value: Covers food, accommodation and international travel, no provision for family members

Length of Study: Up to 4 years

Frequency: Annual

Country of Study: Brazil

No. of awards offered: Up to 50

Application Procedure: Applicants must complete an application form, available on request or from the website. 
Closing Date: August 3rd

Funding: Government

Contributor: Brazilian ministry of science and technology, the Conselho Nacional de Desenvolvimento Cientifico e Tecnologico (CNPq) and TWAS

Additional Information: Please see the website for further details.

\section{CNPq-TWAS Fellowships for Postdoctoral Research in \\ Brazil}

Subjects: All areas of the natural sciences.

Purpose: To enable scholars to pursue postdoctoral research in Brazil. Eligibility: Applicants must have a PhD in the natural sciences, be proficient in English, French, Portuguese or Spanish and must be regularly employed at a research or teaching institution in their home country. Open to nationals of developing countries other than Brazil. The maximum age limit is 45 years.

Level of Study: Postdoctorate

Type: Fellowship

Value: Covers food, accommodation and international travel, no provision for family members

Length of Study: 6 months to 1 year

Frequency: Annual

Country of Study: Brazil

No. of awards offered: Up to 10

Application Procedure: Applicants must complete an application form, available on request or from the website.

Closing Date: September 30th of each year

Funding: Government

Contributor: Brazilian Ministry of Science and Technology, the Conselho Nacional de Desenvolvimento Cientifico e Tecnologico (CNPq) and TWAS

\section{CSIR (Council of Scientific and Industrial Research)/ \\ TWAS Fellowship for Postgraduate Research}

Subjects: Newly emerging areas of science and technology.

Purpose: To enable scholars from developing countries (other than India) who wish to pursue postgraduate research to undertake research in laboratories or institutes of the CSIR.

Eligibility: Candidates must have a Master's or equivalent degree in science or engineering and should be a regular employee in a developing country (other than India) and be holding a research assignment.

Level of Study: Postgraduate

Type: Fellowship

Value: Monthly stipend to cover for living costs, food and health insurance Length of Study: Up to 4 years

Frequency: Annual

Study Establishment: CSIR research laboratories or institutes

Country of Study: India

No. of awards offered: Varies

Application Procedure: One copy of the application should be sent to TWAS and three copies to CSIR. Application forms are available on request or from the website.

Closing Date: June 1st

Funding: Government

Contributor: CSIR (India), the Italian Ministry of Foreign Affairs and the Directorate General for Development Co-operation

No. of awards given last year: 8

Additional Information: CSIR is the premier scientific organization of India, and has a network of research laboratories covering wide areas of scientific and industrial research.

For further information contact:

International S\&T Affairs Directorate, Council for Scientific and Industrial Research (CSIR), Anusandhan Bhavan, 2 Rafi Marg, New Delhi, 110001, India

Fax: (91) 1123710618

Email: rprasad@csir.res.in

Website: http://twas.ictp.it/prog/exchange/fells/fells-pg

Contact: Dr B K Ramprasad, Senior Deputy Advisor

CSIR (The Council of Scientific and Industrial Research)/ TWAS Fellowship for Postdoctoral Research

Subjects: Newly emerging areas of science and technology.
Purpose: To enable scholars from developing countries (other than India) who wish to pursue postdoctoral research to undertake research in laboratories or institutes of the CSIR.

Eligibility: The minimum qualification requirement is a $\mathrm{PhD}$ degree in science or technology. Applicants must be regular employees in a developing country (but not India) and should hold a research assignment. Be a maximum age of 45 years on December 31st of the application year.

Level of Study: Postdoctorate

Type: Fellowship

Value: Monthly stipend to cover for living costs, food and health insurance

Length of Study: Up to 12 months

Frequency: Annual

Study Establishment: CSIR research laboratories or institutes

Country of Study: India

No. of awards offered: Varies

Application Procedure: Applicants must complete an application

form, available on request or from the website.

Closing Date: August 31st

Funding: Government

Contributor: CSIR (India), the Italian Ministry of Foreign Affairs and the Directorate General for Development Co-operation

No. of awards given last year: 4

Additional Information: CSIR is the premier civil scientific organization of India, which has a network of research laboratories covering wide areas of industrial research.

For further information contact:

Senior Deputy Advisor, CSIR (The Council of Scientific and Industrial Research), Anusandhan Bhavan, 2 Rafi Marg, New Delhi, 110001, India Tel: (91) 113316751

Fax: (91) 113710618

Email: rprasad@csirhq.ren.nic.in

Website: http://rdpp.csir.res.in/csir_acsir/PDF/brochure_India.pdf Contact: Dr B K Ramprasad

\section{DBT-TWAS Biotechnology Fellowship for Postdoctoral} Studies in India

Subjects: All areas of biotechnology.

Purpose: To support postdoctoral research in biotechnology in India.

Eligibility: Applicants must have a Master's degree in science or engineering or an equivalent degree and must be a national of a developing country. Indian nationals are not eligible. The maximum age limit is 45 years. Fellowships for $\mathrm{PhD}$ will be awarded only to candidates who are already registered for $\mathrm{PhD}$ in a university in their home country or willing to register in India.

Level of Study: Postgraduate

Type: Fellowship

Value: Monthly stipend to cover for living costs, food and health insurance. The monthly stipend will not be convertible into foreign currency

Length of Study: Maximum 18 months

Frequency: Annual

Study Establishment: More than 80 listed universities and research institutions

Country of Study: India

Application Procedure: Applicants must complete an application form, available on request or from the website.

Closing Date: August 31st

Funding: Government

Contributor: Indian Department of Biotechnology (DBT) and TWAS

\author{
DBT-TWAS Biotechnology Fellowships for Postgraduate \\ Studies in India \\ Subjects: All areas of biotechnology. \\ Purpose: To carry out research leading to a $\mathrm{PhD}$ in biotechnology. \\ Eligibility: Applicants must have a Master's degree in science, \\ engineering or equivalent, must be a national of a developing country \\ (except India) and must be registered for $\mathrm{PhD}$ or be willing to register \\ in India. The maximum age limit is 35 years. \\ Level of Study: Postdoctorate \\ Type: Fellowship
}


Value: DBT will provide a monthly stipend to cover for living costs, food and health insurance. The monthly stipend will not be convertible into foreign currency. In addition, the fellowship holder will receive a house rent allowance

Length of Study: Up to 5 years

Frequency: Annual

Study Establishment: More than 80 listed universities and research institutions

Country of Study: India

No. of awards offered: Up to 40

Application Procedure: Applicants must complete an application

form, available on request or from the website.

Closing Date: August 31st

Funding: Government

Contributor: Indian Department of Biotechnology (DBT) and TWAS

\section{ICSU-TWAS-UNESCO-UNU/IAS Visiting Scientist \\ Programme}

Subjects: All areas of science other than mathematics or physics. Purpose: To provide institutions and research grants in the South, especially in least developed countries (LDCs), with the opportunity to establish long-term links with world leaders in science and help build scientific capacity in their country.

Eligibility: Candidate must be an internationally renowned expert.

Level of Study: Research, Professional development

Type: Consultancy

Value: Travel plus a US $\$ 500$ honorarium. Local costs will be covered by the host institution

Length of Study: Minimum of 1 month

Frequency: Annual

Study Establishment: Teaching and research institutions

Country of Study: Any developing country, preference will be given to LDCs

Application Procedure: Applicants must complete an application

form, available on request or from the website.

Closing Date: October 1st

Funding: Government, international office

Contributor: International Council for Science (ICSU), United Nations Educational, Scientific and Cultural Organization (UNESCO), United Nations University/Institute for Advanced Studies (UNU/IAS) and TWAS No. of awards given last year: 16 visits

Additional Information: A similar programme for mathematics and physics is run by the Abdus Salam International Centre for Theoretical Physics (ICTP). See the website http://portal.unesco.org/science/en/ ev.php-URL_ID $=4672 \& U R L$ DO $=$ DO_TOPIC\&URL_SECTION = 201.html for more information.

\section{Support for International Scientific Meetings}

Subjects: Agricultural, biological, chemical, engineering or geological and medical sciences.

Purpose: To encourage international scientific meetings in Third World countries.

Eligibility: Open to organizers of international scientific meetings in developing countries. Special consideration is given to those meetings that are likely to benefit the scientific community in the Third World and to promote regional and international co-operation in developing science and its applications to the problems of the Third World. Level of Study: Postgraduate, Professional development Type: Travel grant

Value: Up to US $\$ 5,000$ for travel expenses of principal speakers from abroad and/or participants from the region

Frequency: Annual

Country of Study: Developing countries

No. of awards offered: Varies

Application Procedure: Applicants must complete an application form, available on request or from the website.

Closing Date: May 31st

Funding: Government

Contributor: The Italian Ministry of Foreign Affairs and the

Directorate General for Development Co-operation

No. of awards given last year: 30

Additional Information: Grants are not offered for meetings in

Physics and Mathematics.

\section{The Trieste Science Prize}

Subjects: Biological sciences, chemical sciences, agricultural sciences, Earth, space, ocean and atmospheric sciences, engineering sciences, mathematics, medical sciences, physics and astronomy.

Purpose: To honour outstanding scientists living and working in developing countries.

Eligibility: Candidates must be nationals of developing countries living and working in the South. Individuals who have won the Nobel Prize, Tokyo/Kyoto Prize, Gafoord Prize or Abel Prize are not eligible. Level of Study: Research

Type: Prize

Value: US $\$ 50,000$ each

Frequency: Annual

Country of Study: Any developing country

No. of awards offered: 2

Application Procedure: Nomination forms must be downloaded from the website www.twas.org and accompanied by a five- to six-page biographical sketch outlining the nominee's major scientific achievements, pre-prints of up to 20 publications and a complete list of publications.

Closing Date: May 15th

Funding: Commercial, private

Contributor: Illycaffè, Trieste

Additional Information: Please see the website for further details www.twas.org.cn/twas/prizes.asp.

TWAS Fellowships for Research and Advanced Training Subjects: All fields of basic sciences.

Purpose: To enhance the research of young promising scientists, specifically those at the beginning of their research career, and to help them to foster links for future collaboration.

Eligibility: Open to nationals of developing countries with permanent positions in universities or research institutes in developing countries holding a PhD or equivalent. Candidates must not be older than 40 years and preference will be given to candidates from less developed countries

Level of Study: Postdoctorate

Type: Fellowship

Value: Travel support and monthly subsistence of up to US $\$ 300$.

Living expenses are usually obtained from local sources

Length of Study: 3 months to 1 year

Frequency: Annual

Country of Study: Developing countries

No. of awards offered: Varies

Application Procedure: Applicants must complete an application form, available on request or from the website.

Closing Date: October 1st

Funding: Government

Contributor: The Italian Ministry of Foreign Affairs and the

Directorate General for Development Co-operation

Additional Information: Further information is available on the website http://twas.org/opportunity/twas-fellowships-research-andadvanced-training

\section{TWAS Prizes}

Subjects: Medical sciences, biology, chemistry, mathematics and physics, agricultural sciences, engineering sciences and earth sciences.

Purpose: To recognize and support outstanding achievements made by scientists from developing countries. Prizes are awarded to those scientists whose research work has significantly contributed to the advancement of science.

Eligibility: Open to nationals of developing countries who are, as a rule, working and living in these countries. Consideration is given to proven achievements judged particularly by their national and international impact. Members of TWAS are not eligible for such awards.

Level of Study: Postdoctorate, Postgraduate, Professional development, Doctorate

Type: Prize

Value: US $\$ 15,000$ each

Frequency: Annual

Country of Study: Developing countries

No. of awards offered: 8 
Application Procedure: Applicants must be designated on the nomination form. The nomination must be accompanied by a one- to two-page biographical sketch of the nominee including their major scientific accomplishments, a list of 12 of the candidate's most significant publications as well as a complete list of publications and a curriculum vitae. Nominations for the awards are invited from all members of the TWAS as well as from academies, national research councils, universities and scientific institutions in developing countries and advanced countries. A nomination form is available on request or can be downloaded from the website.

Closing Date: February 28th. Nominations received after the deadline will be considered in the next year

Funding: Government

Contributor: The Italian Ministry of Foreign Affairs and the

Directorate General for Development Co-operation

No. of awards given last year: 8

Additional Information: The awards are usually presented on a special occasion, normally coinciding with the general meeting of the Academy and/or a general conference organized by the Academy. Recipients of awards are expected to give lectures about the work for which the awards have been made. Further information is available on the website.

\section{TWAS Prizes to Young Scientists in Developing \\ Countries}

Subjects: Biology, chemistry, mathematics or physics, rotated annually. Purpose: To enable science academies and research councils in developing countries to award prizes to scientists in their countries. Eligibility: Open to academies and research councils in developing countries. The age limit for prize winners is 40 years.

Level of Study: Postgraduate

Type: Prize

Value: Usually US $\$ 2,000$

Frequency: Annual

Country of Study: Developing countries

No. of awards offered: More than 30

Application Procedure: Applicants must write for details to info@twas.org or see the website http://twas.org/opportunity/ twas-prizes-young-scientists-developing-countries.

Closing Date: July 31st

Funding: Government

Contributor: The Italian Ministry of Foreign Affairs and the

Directorate General for Development Co-operation

No. of awards given last year: 23

\section{TWAS Research Grants}

Subjects: Biology, chemistry, mathematics and physics.

Purpose: To reinforce and promote scientific research in basic sciences in the Third World, to strengthen the endogenous capacity in science and to reduce the exodus of scientific talents from the South.

Eligibility: Applicants must be nationals of developing countries with an advanced academic degree, some research experience and must hold positions at universities or research institutions in developing countries.

Level of Study: Doctorate, Postdoctorate, Postgraduate, Professional development

Type: Research grant

Value: Up to US\$10,000. Grants are to be used to purchase scientific equipment, consumable laboratory supplies and scientific literature (textbooks and proceedings only)

Length of Study: 1 year

Frequency: Annual

Country of Study: Developing countries

No. of awards offered: Varies

Application Procedure: Applicants must complete an application form available on request or from the website http://twas.org/opportunities/ research-grants. Applications must be submitted in English.

Closing Date: June 1st

Funding: Government

Contributor: The Italian Ministry of Foreign Affairs, the Directorate

General for Development Co-operation and the Swedish Agency for Research Co-operation with Developing Countries

No. of awards given last year: 90

Additional Information: Further information is available on the request
TWAS Spare Parts for Scientific Equipment

Subjects: Biology, chemistry and physics.

Purpose: The programme has been established in response to the current difficulty faced by several laboratories in the Third World to obtain badly needed spares and replacement parts for scientific equipment that is required for their experimental research.

Eligibility: Applicants must be research group leaders at universities or research institutes in developing countries.

Level of Study: Professional development

Type: Grant

Value: Up to US $\$ 1,000$ including insurance and freight charges

Country of Study: Developing countries

No. of awards offered: Varies

Application Procedure: Applicants must first contact the suppliers and obtain a proforma invoice, valid for 3-6 months, including cost, insurance and freight charges for the items they require. Applicants must submit a completed application form with the proforma invoice from the supplier. Application forms are available on request or from the website.

Closing Date: Applications are accepted at any time

Funding: Government

Contributor: The Italian Ministry of Foreign Affairs and the

Directorate General for Development Co-operation

No. of awards given last year: 30

Additional Information: Applications by email will not be accepted.

For further information contact:

c/o The Abdus Salam International Centre for Theoretical physics Strada Costiera 11-34014, Trieste, Italy

Fax: (39) 39040224559

Website: www.ihep.ac.cn/library/lanmu/xiaoxi/spare.htm Contact: Mrs M.T. Mahdavi

\section{TWAS UNESCO Associateship Scheme}

Subjects: Biology, chemistry, physics, mathematics, engineering, agricultural sciences, medical sciences and earth sciences.

Purpose: To alleviate the problem of isolated talented scientists in developing countries, and strengthen the research programmes of centres of excellence in the South.

Eligibility: Open to associates among the most eminent and promising researchers in developing countries. Special consideration is given to scientists from isolated institutions in developing countries. Level of Study: Postdoctorate, Professional development

Value: Travel costs plus US $\$ 200$ per month for incidental local expenses. The host centre provides local hospitality and research facilities

Length of Study: 3 years, plus the entitlement to visit the Centre twice for a period of 2-3 months each time. There is a possibility of renewal for a further 3 years depending on funds available

Frequency: Annual

Study Establishment: There are over 116 centres

Country of Study: Developing countries

No. of awards offered: Varies

Application Procedure: Applicants must complete an application form, available on request or from the website http://twas.org/ opportunity/twas-unesco-associateship-scheme.

Closing Date: December 1st

Funding: Government

Contributor: UNESCO, the Italian Ministry for Foreign Affairs and the Directorate General for Development Co-operation

\section{TWAS-S N Bose National Centre for Basic Sciences Postgraduate Fellowships in Physical Sciences Subjects: Physical sciences.}

Purpose: To carry out research leading to a PhD in the physical sciences.

Eligibility: Applicant must have a Master's degree in physics, mathematics or physical chemistry, must be a national of a developing country (other than India) and be employed at a research institution. The maximum age limit is 35 years.

Level of Study: Postgraduate

Type: Fellowship

Value: Monthly stipend (INR 8,000 per month as well as free oncampus accommodation, INR 2,400 will be paid towards house rent) to cover living costs, food and health insurance 
Length of Study: Up to 5 years

Frequency: Annual

Study Establishment: S N Bose National Centre for Basic Sciences Country of Study: India

No. of awards offered: Up to 5

Application Procedure: Applicants must complete an application form, available on request or from the website.

Closing Date: August 31st

Funding: Government

Contributor: S N Bose National Centre for Basic Sciences, Kolkata, India and TWAS

Additional Information: For further information see the website http://twas.org/opportunity/twas-sn-bose-postgraduate-fellowshipprogramme.

\section{THURGOOD MARSHALL COLLEGE FUND (TMCF)}

901 F Street NW, Suite 300, Washington, DC, 20004, United States of America

Tel: (1) 2025074851

Fax: (1) 2026522934

Email: info@tmcfund.org

Website: www.thurgoodmarshallfund.org

The Thurgood Marshall College Fund (TMCF) was established in 1987 to carry on Justice Marshall's legacy of equal access to higher education by supporting exceptional merit scholars attending America's public historically Black colleges and universities. More than 5,000 Thurgood Marshall Scholars have graduated and are making valuable contributions to science, technology, government, human service, business, education and various communities.

\section{Philip Morris USA Thurgood Marshall Scholarship}

Subjects: Biology, business, chemistry, computer science, economics, engineering, finance and physics.

Purpose: To aid students who demonstrated financial need and the potential for success.

Eligibility: Open to citizens of the US and current full-time students of Florida A\&M, North Carolina A\&T, Winston-Salem State, Howard University, Virginia State or Norfolk State Universities.

Level of Study: Postgraduate

Type: Scholarships

Value: Up to US $\$ 5,000$

Length of Study: 1 year

Frequency: Annual

Country of Study: United States of America

No. of awards offered: 17

Application Procedure: A completed application form should be submitted to the TMSF College Coordinator.

Closing Date: Check with website

Funding: Foundation

For further information contact:

90 William Street, Suite 1203, New York, NY, 10038, United States of America

Website: www.thurgoodmarshallfund.net/scholarship/about-

scholarships-program

Contact: Philip Morris

\section{TMCF Scholarships}

Subjects: Creative and performing arts.

Purpose: To financially support outstanding students.

Eligibility: Open to candidates who are academically exceptional in the creative and performing arts requiring financial help.

Type: Scholarship

Value: Varies

Frequency: Annual

Application Procedure: Completed applications must be submitted along with the required attachments.

Closing Date: Refer to the website for details: http://tmcf.org/our-

scholarships/current-scholarships

Funding: Foundation

Additional Information: Refer to the website for details: http://tmcf. org/our-scholarships/current-scholarships.
For further information contact:

AIPLEF Scholarship, 80 Maiden Lane, Suite 2204, New York, NY 10038 Email: jessica.barnes@tmcfund.org

Website: www.thurgoodmarshallfund.net/scholarship/about-

scholarships-program

\section{TOKYU FOUNDATION FOR INBOUND STUDENTS}

1-21-2 Dogenzaka, Shibuya Ku, Tokyo, 150-0043, Japan

Tel: (81) 334610844

Fax: (81) 354581696

Email: info@tokyu-f.jp

Website: www.tokyu-f.jp

Contact: Dr Takashi Izumi, Managing Director \& Secretary General

The Tokyu Foundation for Inbound Students grant scholarships to postgraduate students studying in Japan from Asia-pacific areas.

\section{Tokyu Scholarship}

Subjects: All subjects.

Purpose: To promote international exchange by fostering the development of international goodwill between Japan and her neighbours in Asia and the Pacific and contributing to international cooperation and cultural exchange in the broadest possible sense. Eligibility: Open to applicants from Asia or Pacific countries who will be able to explain about their research plan in Japanese. Please check website for complete qualifications.

Level of Study: Postgraduate

Type: Scholarship

Value: $¥ 160,000$ per month per student; travel expenses for attending academic meetings in Japan will be provided

Length of Study: Up to 2 years

Frequency: Annual

Country of Study: Japan

No. of awards offered: $15-20$

Application Procedure: Application forms and guidelines can be downloaded from the foundation's website (in Japanese only)

Closing Date: Between October 1st and November 1st. Applicants must abide by the deadline and submit application

Funding: Commercial

Contributor: Tokyu Corporation

No. of awards given last year: 21

No. of applicants last year: 869

Additional Information: Applicants must travel to Japan at their own cost and be admitted to enter university postgraduate school. Please refer to the website for more information.

For further information contact:

Office for International Cooperation \& Exchange (OICE), Graduate School of Agricultural and Life Sciences, The University of Tokyo Tel: 81358418122 Ext. 25485

Website: www.jpss.jp/en/scholarship/233/

Contact: Dr Neelam Ramaiah

\section{TOLEDO COMMUNITY FOUNDATION}

\author{
300 Madison Avenue, Suite 1300, Toledo, OH, 43604, \\ United States of America \\ Tel: (1) 4192415049 \\ Fax: (1) 4192425549 \\ Email: toledocf@toledocf.org \\ Website: www.toledocf.org
}

The Toledo Community Foundation, Inc. is a public, charitable foundation that exists to improve the quality of life in the Toledo region.

Charles Z. Moore Memorial Scholarship Fund Subjects: Music.

Purpose: To encourage students pursuing a course of study in music with an emphasis on Jazz studies. 
Eligibility: Open to residents of northwest Ohio or Southeast Michigan who demonstrate the talent, interest and ability needed to pursue the study of Jazz.

Level of Study: Professional development

Type: Scholarship

Frequency: Annual

Country of Study: United States of America

Application Procedure: A completed scholarship application form and support materials must be sent.

Closing Date: March 22nd

Additional Information: Please see the website for further details http://asoft4241.accrisoft.com/tcf/main/scholarships/.

\section{Edith Franklin Pottery Scholarship}

Subjects: Ceramic arts.

Purpose: To assist promising and accomplished potters in obtaining additional education or training in the ceramic arts.

Eligibility: Open to all applicants who are current residents of northwest Ohio Lenawee or Monroe Countries in Michigan with individual motivation, ability and potential.

Level of Study: Professional development

Type: Scholarship

Value: US\$7,000

Frequency: Annual

Study Establishment: Any recognized college, university or nonprofit organization

Country of Study: United States of America

Application Procedure: A completed scholarship application form must be sent.

Closing Date: February 28th

Additional Information: Please see the website for further details www.toledocf.org/clientuploads/doc/scholarships/Edith\%20Franklin\% 20App-Other.pdf.

\section{Harold W. Wott-IEEE Toledo Section Scholarship Fund}

Subjects: Engineering.

Purpose: To support students studying in the engineering field Eligibility: Open to applicants attending institutions or universities in northwestern Ohio and southeastern Michigan.

Level of Study: Postgraduate

Type: Scholarship

Value: US $\$ 1,000$

Frequency: Annual

Country of Study: United States of America

No. of awards offered: Varies

Application Procedure: A completed application form and required attachments and transcripts must be sent.

Closing Date: March 1st

Additional Information: Please see the website for further details www.toledocf.org/main/scholarships/.

\section{TOMSK POLYTECHNIC UNIVERSITY}

Institute for International Education and Language Communication, Tomsk Polytechnic University, 30, Lenin prospect, Tomsk, 634050, Russia Tel: (7) 3822563304 Fax: (7) 3822564500 Email: iie@tpu.ru Website: www.iie.tpu.ru

Tomsk Polytechnic University was founded in 1896 and is the oldest technical educational institution in the Asian part of Russia. Since that time, the university scholars and graduates have greatly contributed to the Russian science, education, culture and industry development.

Tomsk Polytechnic University International Scholarship Subjects: All subjects available at the university.

Purpose: To financially support outstanding students.

Eligibility: Open to candidates with an average of 80 per cent marks at graduation, who are not older than 40 years of age.

Level of Study: Postgraduate, Doctorate
Type: Scholarships

Value: Varies

Length of Study: $1-3$ years

Frequency: Annual

Study Establishment: Tomsk Polytechnic University

Country of Study: Russia

No. of awards offered: 5

Application Procedure: Applicants can download the application form from the website. The completed application form and educational certificates must be submitted.

Closing Date: August 15th

Funding: Corporation, government

Contributor: Ministry of Russian Federation

No. of awards given last year: 3

No. of applicants last year: 50

Additional Information: Applications are to be submitted by fax at 3822563304 or by email to iie@tpu.ru.

\section{TOURETTE SYNDROME ASSOCIATION, INC. (TSA)}

42-40 Bell Boulevard, Suite 205, Bayside, NY, 11361-2820, United States of America Tel: (1) 7182242999

Fax: (1) 7182799596

Email: ts@tsa-usa.org

Website: www.tsa-usa.org

Contact: Dr Kevin St P McNaught, Vice President, Medical \& Scientific Programmes

The Tourette Syndrome Association, Inc. (TSA), founded in 1972, is the only national voluntary non-profit membership organization dedicated to identifying the cause, finding the cure and controlling the effects of Tourette Syndrome. Members include individuals with the disorder, their relatives and other interested, concerned people. The Association develops and disseminates educational material to individuals, professionals and agencies in the fields of healthcare, education and government, co-ordinates support services to help people and their families cope with the problems that occur with Tourette Syndrome and funds research that will ultimately find the cause of and cure for it and, at the same time, lead to improved medications and treatments.

\section{TSA Research Grant and Fellowship Program}

Subjects: Clinical and basic science relevant to Tourette Syndrome.

Purpose: To foster basic and clinical research related to the causes or treatment of Tourette Syndrome.

Eligibility: Open to candidates who have an MD, PhD or equivalent qualifications. Previous experience in the field of movement disorders is desirable, but not essential. Fellowships are intended for young postdoctoral investigators in the early stages of their careers.

Level of Study: Research, Postdoctorate

Type: Research grant

Value: Varies, depending upon the category and applicant's experience within that category, and up to US $\$ 75,000$ for 1 year or up to US $\$ 150,000$ for 2 years. Postdoctoral grants training (fellowships) are up to US $\$ 50,000$

Length of Study: 1 year

Frequency: Annual

Study Establishment: Any institution with adequate facilities

Country of Study: Any country

No. of awards offered: Varies

Application Procedure: Applicants must submit a letter of intent briefly describing the scientific basis of the proposed project. For further information and deadlines please see the www.tsa-usa.org/ research.html.

Closing Date: Pre-proposal Deadline: November 1st each year and Proposal Deadline: February 12th each year

Funding: Private

No. of awards given last year: 10

No. of applicants last year: 65

Additional Information: The Association provides up to 10 per cent of overhead or indirect costs within the total amount budgeted. 


\section{TOXICOLOGY EDUCATION FOUNDATION (TEF)}

626 Admiral Drive, Ste. C, PMB 221, Annapolis, MD, 21401, United States of America

Tel: (1) 4433214654

Fax: (1) 4433218702

Email: tefhq@toxedfoundation.org

Website: www.toxedfoundation.org

The mission of TFE is to encourage, support and promote charitable and educational activities that increase the public understanding of toxicology.

\section{Alleghery-ENCRC Student Research Award}

Subjects: Toxicology.

Purpose: To support a student's thesis, dissertation and summer research project in toxicology and to encourage them to formulate and conduct meaningful research.

Eligibility: Open to students who are members in good standing of AE-SOT. The student's advisor must also be a member in good standing and submit a letter concerning availability.

Level of Study: Graduate

Type: Award

Value: Up to $\$ 1,000$

Frequency: Annual

Country of Study: United States of America

No. of awards offered: 1

Application Procedure: Applicants must send four copies of completed application form along with a project description and budget.

Closing Date: May 30th

For further information contact:

CDC/NIOSH MS 2015, 1095 Willowdale Road, Morgatown, WV, 26505, United States of America

Email: LBattelli@cdc.gov

Contact: Lori Battelli

\section{Colgate-Palmolive Grants for Alternative Research}

Subjects: Reproductive and developmental toxicology, neurotoxicology, systemic toxicology, sensitization and acute toxicity.

Purpose: To identify and support efforts that promote, develop, refine or validate scientifically acceptable animal alternative methods to facilitate the safety assessment of new chemicals and formulations. Level of Study: Research

Type: Research grant

Value: Plaque and maximum award of $\$ 40,000$

Frequency: Annual

Country of Study: United States of America

Application Procedure: Application is available online. A research plan, budget, curriculum vitae and a letter from the institution must be sent.

Closing Date: October 9th

Funding: Private

Contributor: Colgate-Palmolive

No. of awards given last year: 5

\section{Colgate-Palmolive Postdoctoral Fellowship Award in In Vitro Toxicology}

Subjects: Toxicology.

Purpose: To advance the development of alternatives to animal testing in toxicological research.

Eligibility: Open to postdoctoral trainees employed by academic institutions. The applicants or postdoctoral advisors must be members or pending members of SOT.

Level of Study: Postdoctorate

Type: Fellowship

Value: Includes a stipend and research-related costs of up to US $\$ 44,000$ for 1 year

Length of Study: 1-3 year

Frequency: Every 2 years, alternate year

Country of Study: United States of America

Application Procedure: Applicants must submit their curriculum vitae, transcripts, research proposal, budget and recommendation letters. Applicants must also supply a description of the research to be performed.

Closing Date: October 9th

Contributor: Colgate-Palmolive

Additional Information: Preference is for applicants in their 1st year of study beyond the PhD, MD or DVM degree. Funding for 2 nd year is contingent upon satisfactory research progress.

For further information contact:

Website: www.toxicology.org/ai/af/awards.aspx

\section{Food Safety SS Burdock Group Travel Award}

Subjects: Food safety toxicology.

Purpose: To cover travel expenses for a student to attend the Annual Meeting.

Eligibility: Open to full-time graduate students with research interests in toxicology. Students in their early graduate training, who have not attended any SOT Annual Meeting are encouraged to apply.

Level of Study: Graduate

Value: Up to $\$ 500$

Frequency: Annual

Country of Study: United States of America

No. of awards offered: 3

Application Procedure: Applicants must send a letter of request indicating that he/she is enrolled in good standing in a doctoral training programme. The applicant must also state how the research and training relate to food safety.

Closing Date: February 24th

For further information contact:

Email: rmatulka@burdockgroup.com

Website: http://www.toxicology.org/ai/af/awards_details.aspx?id=59 Contact: Ray Matulka

\section{Regulation and Safety SS Travel Award}

Subjects: Toxicology

Purpose: To help defray the costs of travel to the SOT meeting

Eligibility: Open to students submitting a poster or making a presentation at the SOT meeting.

Type: Travel award

Value: $\$ 1,500$ each

Frequency: Annual

Country of Study: United States of America

No. of awards offered: $4-5$

Application Procedure: Applicants must fill an application form and an abstract of work preserved.

Closing Date: December 15th

For further information contact:

Email: jtmacgror@earthlink.net

Website: www.toxicology.org/ISOT/SS/regulatorysafety/awards.asp Contact: James TMacGregor

\section{Robert L. Dixon International Travel Award}

Subjects: Reproductive toxicology.

Purpose: To financially assist students studying in the area of reproductive toxicology.

Eligibility: Open to applicants enrolled full-time in a $\mathrm{PhD}$ programme studying reproductive toxicology and are student members of SOT.

Level of Study: Doctorate, Graduate

Type: Award

Value: Includes a stipend of US $\$ 2,000$ for travel costs to enable

students to attend the International Congress of Toxicology meeting

Frequency: Every 3 years

Country of Study: United States of America and abroad

Application Procedure: Applicants must submit a completed application form, reference letter, graduate transcripts and lists of complete citations of the original work.

Closing Date: October 9th (check with website)

Contributor: Toxicology Education Foundation

For further information contact:

Email: tefhq@toxedfoundation.org

Website: www.toxedfoundation.org/dixon_award.htm 


\section{THE TOYOTA FOUNDATION}

37F, Shinjuku-Mitsui Building, 2-1-1, Nishi-Shinjuku, Shinjuku-Ku, Tokyo, 163-0437, Japan

Tel: (81) 333441701

Fax: (81) 333426911

Email: admin@toyotafound.or.jp

Website: www.toyotafound.or.jp

The Toyota Foundation was established in 1974 as a multi-purpose grant-making foundation. It provides financial assistance to carry out projects in Japan and other countries, mainly in the developing world, that address timely issues in a variety of fields.

\section{The Toyota Foundation Research Programme}

Subjects: All subjects.

Purpose: To support research.

Eligibility: Open to candidates of all nationalities studying a doctoral programme.

Type: Scholarship

Value: Varies

Length of Study: $1-2$ years

Frequency: Annual

Application Procedure: Please see the website for details.

Closing Date: May 16th (via the Internet), May 12th (by postal mail)

Funding: Foundation

Contributor: The Toyota Foundation

\section{TRANSPORTATION ASSOCIATION OF CANADA FOUNDATION}

\author{
2323 St Laurent Boulevard, Ottawa, ON, K1G 4J8, \\ Canada \\ Tel: (1) 6137361350 , ext. 235 \\ Fax: (1) 6137361395 \\ Email: secretariat@tac-atc.ca \\ Website: www.tac-atc.ca \\ Contact: Ms Deb Cross, Secretary-Treasurer
}

The Transportation Association of Canada Foundation has a mandate to support the educational and research needs of the Canadian transportation industry.

\section{TAC Foundation - 3M Canada Bob Margison Memorial Scholarship}

Subjects: Transportation-related disciplines.

Eligibility: Open only to the Canadian candidates or landed immigrants who are admissible to a postgraduate studies program or already registered as full-time graduate students having a minimum grade point average of $B$.

Level of Study: Postgraduate

Type: Scholarship

Value: $\$ 4,500$

Length of Study: 4 years

Application Procedure: Check the website for further details.

Closing Date: February 11th (check with website)

Contributor: $3 \mathrm{M}$ Canada Bob Margison Memorial

\section{TAC Foundation - Albert M. Stevens Scholarship}

Subjects: Transportation-related disciplines.

Purpose: To contribute to maintain high quality transportation expertise in Canada.

Eligibility: Open only to the Canadian candidates or landed immigrants who are admissible to a postgraduate studies programme or already registered as full-time graduate students having a minimum grade point average of $B$.

Level of Study: Postgraduate

Type: Scholarship

Value: $\$ 5,000$

Length of Study: 4 years

Application Procedure: Applicants must send application form (including a two page curriculum vitae) to the TAC Foundation.

Closing Date: February 13th

Funding: Individuals
Contributor: Albert M. Stevens

Additional Information: Please see the website for further details

http://tac-atc.ca/en/about-us/tac-foundation/scholarships.

\section{TAC Foundation - Cement Association of Canada \\ Scholarship \\ Subjects: Transportation-related disciplines.}

Purpose: To recognize the importance of education in the transportation field

Eligibility: Open only to the Canadian candidates or landed immigrants who are admissible to a postgraduate studies program or already registered as full-time graduate students having a minimum grade point average of B.

Level of Study: Postgraduate

Type: Scholarship

Value: $\$ 5,000$

Length of Study: 4 years

Application Procedure: Applicants must send application form (including a two page curriculum vitae) to the TAC Foundation.

Closing Date: February 11th

Contributor: Cement Association of Canada

\section{TAC Foundation - Delcan Corporation Scholarship}

Subjects: Transportation-related disciplines.

Eligibility: Open only to Canadian candidates or landed immigrants who are admissible to a postgraduate studies program or already registered as full-time graduate students having a minimum grade point average of $B$.

Level of Study: Postgraduate

Type: Scholarship

Value: $\$ 5,000$

Length of Study: 4 years

Application Procedure: Applicants must send application form (including a two page curriculum vitae) to the TAC Foundation.

Closing Date: February 11 th (check with website)

Contributor: Delcan Corporation

\section{TAC Foundation - EBA Engineering Consultants Ltd Scholarship}

Subjects: Transportation engineering.

Eligibility: Open only to Canadian candidates or landed immigrants who are admissible to a postgraduate studies program or already registered as full-time graduate students having a minimum grade point average of $B$.

Level of Study: Postgraduate

Type: Scholarship

Value: $\$ 5,000$

Length of Study: 4 years

Application Procedure: Applicants must send application form (including a two page curriculum vitae) to the TAC Foundation.

Closing Date: February 11th (check with website)

Contributor: EBA Engineering Consultants Limited

Additional Information: Preference is given in the areas of design, construction, maintenance and operation of roadway transportation systems in rural and urban environments.

\section{TAC Foundation - HDR/iTRANS Scholarship}

Subjects: Transportation-related disciplines.

Purpose: To foster education, innovation, and research in transportation planning and transportation engineering.

Eligibility: Open only to Canadian candidates or landed immigrants who are admissible to a postgraduate studies program or already registered as full-time graduate students having a minimum grade point average of $B$.

Level of Study: Postgraduate

Type: Scholarship

Value: $\$ 5,000$

Length of Study: 4 years

Application Procedure: Applicants must send application form (including a two page curriculum vitae) to the TAC Foundation.

Closing Date: February 11th (check with website)

Contributor: HDR/ITRANS 
TAC Foundation - IBI Group Scholarship

Subjects: Transportation-related disciplines.

Purpose: To attract and prepare transportation planners, providers, funders, and users for a career in the transportation industry.

Eligibility: Open only to Canadian candidates or landed immigrants who are admissible to a postgraduate studies program or already registered as full-time graduate students having a minimum grade point average of $B$.

Level of Study: Postgraduate

Type: Scholarship

Value: $\$ 4,500$

Length of Study: 4 years

Application Procedure: Applicants must send application form (including a two page curriculum vitae) to the TAC Foundation.

Closing Date: February 11 th

Contributor: IBI Group

\section{TAC Foundation - Municipalities Scholarship}

Subjects: Transportation-related disciplines.

Purpose: To attract and prepare transportation planners, providers, funders, and users for a career in the transportation industry.

Eligibility: Open only to Canadian candidates or landed immigrants who are admissible to a postgraduate studies program or already registered as full-time graduate students having a minimum grade point average of $B$.

Level of Study: Postgraduate

Type: Scholarship

Value: $\$ 3,000$

Length of Study: 4 years

Application Procedure: Applicants must send application form (including a two page curriculum vitae) to the TAC Foundation. Closing Date: February 11th (check with website)

Contributor: Municipalities

\section{TAC Foundation - Provinces and Territories}

\section{Scholarship}

Subjects: Transportation-related disciplines.

Purpose: To attract and prepare transportation planners, providers, funders, and users for a career in the transportation industry.

Eligibility: Open only to Canadian candidates or landed immigrants who are admissible to a postgraduate studies program or already registered as full-time graduate students having a minimum grade point average of $B$.

Level of Study: Postgraduate

Type: Scholarship

Value: $\$ 5,000$

Length of Study: 4 years

Application Procedure: Applicants must send application form (including a two page curriculum vitae) to the TAC Foundation.

Closing Date: February 11th (check with website)

Contributor: Provinces and territories

\section{TAC Foundation - Stantec Consulting Ltd Scholarship}

Subjects: Transportation engineering.

Purpose: To encourage students to continue their postgraduate studies in the field of transportation engineering and to contribute to the cost-effective mobility upon which our society is based. Eligibility: Open only to Canadian candidates or landed immigrants who are admissible to a postgraduate studies program or already registered as full-time graduate students having a minimum grade point average of $B$

Level of Study: Postgraduate

Type: Scholarship

Value: $\$ 5,000$

Length of Study: 4 years

Application Procedure: Applicants must send application form (including a two page curriculum vitae) to the TAC Foundation. Closing Date: February 11th (check with website)

Contributor: Stantec Consulting Ltd

\section{TAC Foundation - Waterloo Alumni Scholarship}

Subjects: Transportation-related disciplines.

Purpose: To continue the tradition of providing financial assistance to postgraduate students in the broad area of transportation.
Eligibility: Open only to Canadian candidates or landed immigrants who are admissible to a postgraduate studies program or already registered as full-time graduate students having a minimum grade point average of $B$.

Level of Study: Postgraduate

Type: Scholarship

Value: $\$ 7,500$

Length of Study: 4 years

Application Procedure: Applicants must send application form (including a two page curriculum vitae) to the TAC Foundation. Closing Date: February 11th (check with website)

Contributor: University of Waterloo Alumni who are past recipients of Transportation Association of Canada scholarships

Additional Information: Preference will be given to qualified candidates pursuing their work in the pavement field.

\section{TAC Foundation Scholarships}

Subjects: Road and transportation-related disciplines.

Purpose: To supports the educational needs of the Canadian transportation industry.

Eligibility: Open to Canadian citizens and landed immigrants who hold university degrees and who are acceptable to the university at which they plan to carry out their studies in the transportation field. See website for full details.

Level of Study: Graduate, Postgraduate

Type: Scholarship

Value: Canadian $\$ 3,000-5,000$, with one Canadian $\$ 10,000$ scholarship and one Canadian $\$ 7,500$ scholarship

Length of Study: 1 year

Frequency: Annual

Study Establishment: Universities

Country of Study: Other

No. of awards offered: 15

Application Procedure: Online applications only.

Closing Date: February 13th

Funding: Commercial, government, private

No. of awards given last year: 39

Additional Information: Scholarships currently offered are from the DELCAN Corporation, Stantec Consulting Limited, provincial and territorial governments of Canada, EBA Engineering Consultants Limited, Dillon Consulting Limited, 3M Company, IBI Group, Armtec, HDR/iTRANS, Cement Association of Canada, Waterloo Alumni, Albert Stevens, McCormick Rankin Corporation. Please see the website for further details.

\section{TREE RESEARCH \& EDUCATION ENDOWMENT FUND}

Tree Fund, 552 So. Washington St., Suite 109, Naperville, IL, 60540, United States of America

Tel: (1) 6303698300

Fax: (1) 6303698382

Email: treefund@treefund.org

Website: www.treefund.org

Contact: Ms J Eric Smith, President/CEO

We support scientific discovery and dissemination of new knowledge in the fields of arboriculture and urban forestry.

\section{Hyland R Johns Grant Program}

Subjects: Arboricultural, urban and community forestry.

Purpose: To provide funding for research.

Eligibility: Open to qualified researchers of any nationality.

Level of Study: Research

Type: Research grant

Value: Up to US $\$ 50,000$

Length of Study: $2-5$ years

Frequency: Dependent on funds available

Country of Study: Any country

No. of awards offered: $1-7$

Application Procedure: Applicants must complete an online application form.

Closing Date: April 1st

Funding: Foundation, private

No. of awards given last year: 3 
No. of applicants last year: 30

Additional Information: Please see the website for further details www.treefund.org

\section{Jack Kimmel International Grant Program}

Subjects: Arboricultural, urban and community forestry.

Purpose: To provide money to support projects.

Eligibility: Open to qualified researchers of any nationality.

Level of Study: Research

Type: Research grant

Value: Up to US $\$ 10,000$

Length of Study: $1-3$ years

Frequency: Dependent on funds available

No. of awards offered: $1-3$

Application Procedure: Applicants must complete a two-page

application form, available online at www.treefund.org.

Closing Date: October 1st

Funding: Private, foundation

Contributor: Canadian Tree Fund

No. of awards given last year: 2

No. of applicants last year: 36

Additional Information: Please see the website for further details www.treefund.org/grants/research-grants.

\section{John Z Duling Grant Program}

Subjects: Arboricultural, urban and community forestry.

Purpose: To provide money to support projects.

Eligibility: Open to qualified researchers of any nationality.

Level of Study: Research

Type: Research grant

Value: Maximum grant award of $\$ 25,000$

Length of Study: $1-3$ years

Frequency: Dependent on funds available

Country of Study: Any country

No. of awards offered: $1-10$

Application Procedure: Applicants must complete a two-page

application form, available online at www.treefund.org.

Closing Date: October 1st

Funding: Foundation

No. of awards given last year: 2

No. of applicants last year: 28

Additional Information: Please see the website for further details www.treefund.org/grants/research-grants.

\section{TRIANGLE COMMUNITY FOUNDATION}

324 Blackwell Street, Suite 1220, Durham, NC, 27701, United States of America

Tel: (1) 9194748370

Fax: (1) 9199419208

Email: info@trianglecf.org

Website: www.trianglecf.org

Triangle Community Foundation connects philanthropic resources with community needs, creates opportunity for enlightened change and encourages philanthropy as a way of life.

\section{Shaver-Hitchings Scholarship}

Purpose: To provide financial aid and honour individuals with a commitment to helping others in the area of drug and alcohol addiction.

Eligibility: Applicants must reside in Chatham, Durham, Orange or Wake countries, and be enrolled or planning to enroll in graduate school, a physician assistant programme of study or continue a programme in which the applicant is already enrolled. The student need not be pursuing a degree in addictive disorders, but must show demonstrated commitment to working with others in that field during or before graduate studies, preferably as a volunteer.

Level of Study: Graduate

Type: Scholarship

Value: US $\$ 1,500$

Frequency: Annual

Country of Study: United States of America

No. of awards offered: 1
Application Procedure: Application forms are available online. Closing Date: March 15th

Funding: Foundation

Contributor: Triangle Community Foundation

No. of awards given last year: 1

No. of applicants last year: 6

Additional Information: The scholarship is available to any graduate student, physician's assistant or medical student in the Triangle area who has worked (preferably as a volunteer) to help others with alcoholism, drug abuse and addictive disorder treatment or with preventive education on the subject of addiction. Please see the website for further details www.trianglecf.org/grants_support/view_ scholarships/shaver-hitchings_scholarship/.

\section{TROPICAL AGRICULTURAL RESEARCH AND HIGHER EDUCATION CENTER (CATIE)}

\author{
7170 Cartago, Turrialba, 30501, Costa Rica \\ Tel: (506) 25582000 \\ Fax: (506) 25582060 \\ Email: posgrado@catie.ac.cr \\ Website: www.catie.ac.cr \\ Contact: Dean of the Graduate School
}

The Tropical Agricultural Research and Higher Education Center (CATIE) is an international, non-profit, regional, scientific and educational institution. Its main purpose is research and education in agricultural sciences, natural resources and related subjects in the American tropics, with emphasis on Central America and the Caribbean.

\section{Scholarship Opportunities Linked to CATIE's Postgraduate Program Including CATIE Scholarship Forming Part of the Scholarship-Loan Program}

Subjects: Ecological agriculture, biotechnology and genetic resources, management and conservation of tropical forestry and biodiversity, tropical woodlands, tropical agroforestry, tropical crop protection and improvement, integrated watershed management and protected areas and environmental socioeconomics and rural enterprise development.

Purpose: To develop specialized intellectual capital in clean technology, tropical agriculture, natural resources management and human resources in the American tropics.

Eligibility: Priority is given to citizens of Belize, Guatemala, E Salvador, Honduras, Nicaragua, Panama, Costa Rica, Mexico, Venezuela, Colombia, the Dominican Republic, Bolivia and Paraguay. Level of Study: Doctorate, Postgraduate

Type: Scholarship

Value: Tuition and fees

Length of Study: 2 years for a Master's degree and 3-4 years for a $\mathrm{PhD}$

Frequency: Annual

Country of Study: Costa Rica

No. of awards offered: CATIE offers approx. 30 scholarships per year. Scholarships from other sources vary in origin and number. Information is available on the CATIE website

Application Procedure: Applicants must undertake an admission process that constitutes 75 per cent for curricular evaluation and 25 per cent for a domiciliary examination. Please refer to the CATIE website for full instructions.

Closing Date: Applications are accepted at any time, but the evaluation deadline for Scholarship-Loan Program is late October. Other sources of financing have specific requirements available on CATIE website. These change considerably over time

Funding: Foundation, government, international office, private Contributor: ASDI, OAS, CATIE, DAAD, CONACYT (Mexico), Ford Foundation, Kellogg Foundation, Joint/Japan World Bank. USAID provided the original donation for the endowment financing the Scholarship-Loan Program, SENACYT and Belgium Cooperation No. of awards given last year: 32 in the Scholarship-Loan Program. Over 25 students received funding from alternative sources No. of applicants last year: 350 


\section{THE TRUST COMPANY}

Level 15, 20 Bond Street, GPO Box 4270, New South Wales, Sydney, NSW 2001, Australia

Tel: (61) 0282958100

Fax: (61) 0282958659

Email: scholarships@thetrustcompany.com.au

Website: thetrustcompany.com.au/philanthropy/awards

The Trust Company is manager at a number high profile awards and scholarships made possible through Charitable bequests/trusts. These include the Miles Franklin Literary Award, Kathleen Mitchell Award (literary), Portia Geach Memorial Award (for female artists), the Sir Robert William Askin Operatic Travelling Scholarship (for male singers), the Lady Mollie Isabelle Askin Ballet Travelling Scholarship, and the Marten Bequest Travelling Scholarship.

Lady Mollie Isabelle Askin Ballet Travelling Scholarship Subjects: Contemporary or classical ballet.

Purpose: To support the advancement of culture and education in Australia and elsewhere. To reward Australian citizens of outstanding ability and promise in ballet.

Eligibility: Open to Australian citizens who are over the age of 17 and under the age of 30 at the closing date for entries for the award.

Level of Study: Unrestricted

Type: Scholarship

Value: Australian $\$ 20,000$ each to be paid in four instalments of $\$ 5,000$ over 2 years

Length of Study: More than 2 years

Frequency: Every 2 years

Country of Study: Any country

No. of awards offered: 3

Application Procedure: Applicants must complete an application

form to be submitted with specified documents and enclosures.

Closing Date: September 24th

Funding: Trusts

Contributor: The Estate of Lady Mollie Isabelle Askin

Additional Information: Please refer to www.thetrustcompany.com. au/philanthropy.

\section{Marten Bequest Travelling Scholarships}

Subjects: Scholarships are available in each of the following categories, which rotate in two groups on an annual basis as follows: first category - architecture, ballet, instrumental music, poetry and prose. Second category - acting, painting, sculpture and singing. Purpose: To augment a scholar's own resources towards affording him or her a cultural education by means of a travelling scholarship. Eligibility: To be eligible for this award, you must be an Australian born and aged 21-35 (17-35 for ballet) at the closing date of entries. Level of Study: Unrestricted

Type: Travel grant

Value: Australian $\$ 20,000$

Length of Study: 2 years

Frequency: Annual

Country of Study: Any country

No. of awards offered: Up to 3

Application Procedure: Applicants must complete an application

form online and submit this with a study outline and supporting material as required.

Closing Date: Please refer to http://thetrustcompany.com.au/awards/ marten-bequest-travelling-scholarships/

Funding: Trusts

Contributor: The estate of the late John Chisholm Marten

No. of awards given last year: 11

\section{Miles Franklin Literary Award}

Subjects: Writing.

Purpose: To reward the novel of the year that is of the highest literary merit and presents Australian life in any of its phases.

Eligibility: Refer to the application form. The novel must have been first published in any country in the year preceding the award.

Biographies, collections of short stories, children's books and poetry are not eligible. All works must be in English.

Level of Study: Unrestricted

Type: Award

Value: Australian $\$ 60,000$
Frequency: Annual

Country of Study: Any country

No. of awards offered: 1

Application Procedure: Applicants must complete an application

form and send six copies of their novel.

Funding: Trusts

Contributor: The estate of the late Miss SMS Miles Franklin

No. of awards given last year: 1

Additional Information: If there is no novel worthy of the prize, the award may be given to the author of a play. Please refer to the website for further details: www.milesfranklin.com.au/

\section{For further information contact:}

Email: trustawards@thetrustcompany.com.au stating

Website: www.milesfranklin.com.au

\section{Portia Geach Memorial Award}

Subjects: Visual Arts.

Purpose: To award the best portraits painted from life of a man or woman distinguished in art, letters or the sciences, by a female artist. Eligibility: Entrants must be female Australian residents who are either Australian or British-born or naturalized. Works must be executed entirely in the previous year.

Level of Study: Unrestricted

Type: Award

Value: Australian $\$ 30,000$

Frequency: Annual

Country of Study: Any country

No. of awards offered: 1

Application Procedure: Applicants must complete an application form online and submit this with an entry fee and a digital image of their work.

Closing Date: Please refer to www.thetrustcompany.com.au/ philanthropy

Funding: Trusts

Contributor: The estate of the late Miss Florence Kate Geach

No. of awards given last year: 1

Additional Information: The winning portrait and selected works are exhibited for 1 month at the S H Ervin Gallery in Sydney, Australia.

\section{Sir Robert William Askin Operatic Travelling \\ Scholarship}

Subjects: Operatic singing.

Purpose: To support the advancement of culture and education in Australia and elsewhere. To reward male Australian citizens of outstanding ability and promise as an operatic singer.

Eligibility: Applicants must be male Australian citizens between the ages of 18 and 30 at the time of application.

Level of Study: Unrestricted

Type: Scholarship

Value: Australian $\$ 20,000$ over 2 years

Length of Study: 2 years

Frequency: Every 2 years

Country of Study: Any country

No. of awards offered: 3

Application Procedure: Applicants must complete an application form to be submitted along with specified documents and enclosures. Closing Date: Please refer to www.thetrustcompany.com.au/ philanthropy

Funding: Trusts

Contributor: The estate of Lady Mollie Askin

\section{TUYF CHARITABLE TRUST}

NGO Scholarship Selection Committee c/o Mr Francis Hon, HSBC Trustee (Hong Kong) Limited, Level 13, HSBC Main Building, 1 Queen's Road Central, Hong Kong Email: francis.y.l.hon@hsbcpb.com

TUYF Charitable Trust Scholarship for NGO Governance Subjects: All subjects.

Purpose: The Scholarship supports individuals who wish to pursue an undergraduate or postgraduate degree overseas in Non-Government 
Organization ('NGO') governance or related areas. The purpose of the scholarship is to nurture future leaders and enhance governance of welfare NGOs.

Eligibility: All applicants have to be permanent residents of Hong Kong and must possess undergraduate or postgraduate degree in social studies or relevant subjects, and at least 1 year of work experience in NGOs in Hong Kong, or be fresh graduates who have completed NGO work experience in Hong Kong prior to pursuing their degree, or be an individual with over 3 years of work experience in a management/leadership position in the NGOs in Hong Kong. Please check the website for more details.

Level of Study: Graduate, Postgraduate, Undergraduate

Type: Scholarship

Value: The value of each award shall depend on the expenses

involved in the countries in which the awardee will undertake his/her studies as overseas student. The award may include tuition fees, field placement expenses, accommodation, living expenses and travel costs

Frequency: Annual

No. of awards offered: 2

Application Procedure: All applications must be made on the prescribed application form. All completed applications, together with all relevant supporting documents, must be addressed to The TUYF Charitable Trust NGO Scholarship Selection Committee c/o Mr Francis Hon or sent by email to francis.y.I.hon@hsbcpb.com with subject of 'Application: TUYF NGO Scholarship'.

Closing Date: December 12th

Additional Information: The Funding Organization is under no obligation to make awards in any given year if no suitable candidates are found. 